\title{
The Effect of Incubation Time on Various Type of Local Agricultural Waste in Madiun, Indonesia to Produce Cellulases using Trichoderma viride
}

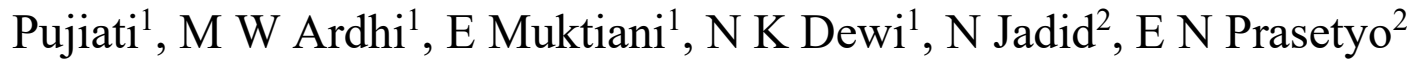 \\ ${ }^{1}$ Biology Education Department, Universitas PGRI Madiun \\ ${ }^{2}$ Biology Department, Institut Teknologi Sepuluh Nopember \\ *Corresponding author.Email: pujiati@unipma.ac.id
}

\begin{abstract}
This study aims to determine the effect of substrate types on the crude activity of cellulase enzymes from local agricultural waste such as peanut shells, coconut fibers, brans, and teak leaves with the variations of incubation times (day 1, 3, 5, and 7) produced by Trichoderma viride. Enzyme activity was measured based on the amount of reducing sugar that produced by the DNS (Dinitrosalycilic Acid) method on a wavelength of $540 \mathrm{~nm}$ spectrophotometer. The results showed that the best substrate for cellulase production on coconut fibers substrate with an incubation period of 7 days which had the highest enzyme activity value of $1.340 \mathrm{U} / \mathrm{ml}$. Coconut fibers contain the highest cellulose content compared to the other substrates. The lowest activity was shown by coconut fibers substrate at day one incubation time of $0.660 \mathrm{U} / \mathrm{ml}$ with the reducing sugar content of $0.594 \mathrm{mg} / \mathrm{ml}$ and protein content of $0.147 \mathrm{mg} / \mathrm{ml}$. The complexity of the chemical composition of coconut fibers caused the longer time to degrade cellulose into glucose at day one than other three substrates.
\end{abstract}

Key words: Incubation, Waste, Trichoderma viride

\section{INTRODUCTION}

Enzymes play important role in the industry. Enzymes become particular item of industry because with their use, energy can be saved and friendly to the environment. The enzymes that have entered the market are mostly derived from the class of hydrolytic enzymes, which are still produced conventionally and they are not optimal and imported from other countries. The need for enzymes is increasing every year. Indonesia was estimated to use enzymes reaching 2,500 tons with import values of around 200 billion Rupiah in 2017. Examples of enzymes that play important role in industrial applications are protease, xylanase, lactase, manase, chitinase, amylase, and cellulase. Cellulase is a commercial enzyme that has a very high selling value. In the 2011 Merck catalog, the price of $5 \mathrm{~g}$ cellulase (cellulose Onozuka R-10 from Trichoderma viride) pack is around $\$ 3,000$, and $25 \mathrm{~g}$ cellulase pack is around $\$ 12,000$. Cellulase sales continue to experience growth of up to $4 \%$ per year [1]. Nowadays, cellulase is widely used in various purposes in the industry. In the textile industry, cellulase is used in the process of finishing and bio blasting of fabrics. In the paper industry, cellulase is used to increase fiber softness. In the detergent industry, cellulase is used to increase color brightness and soften cotton. Cellulase is also widely used in the foods, medicines and cosmetics industries such as anticholesterimic, hypolipemic, oil absorber, or moisturising agents [2] , as well as management of waste resource recycling and anti-pollution treatments [3]. Microbial cellulases also used in, 
animal feed, brewery, wine, , laundry, and agriculture as well [4]. Cellulase enzyme can be produced by cellulolytic microorganisms such as molds and bacteria. Some types of molds known as cellulaseproducing are Penicillium, Phanerochaete, Schizophillum spp, Humicola, Fusarium, Microbispora, and Trichoderma. Trichoderma reesei and Trichoderma viride are known as fungi that have the best cellulolytic ability [5]-[7]. Cellulaseproducing bacterias are Bacteroides, Ruminococcus, Erwinia, Clostridium, Cellumonas, Bacillus, Acetovibrio, Streptomyces and Thermomonospora. Cellulolytic fungi can easily be screened within two days for the production of cellulolytic enzymes (especially, endoglucanase and exoglucanase) by staining technique or by measuring the amount of reducing sugar (glucose) produced with the dinitrosalicyclic acid reagent method [8]. Cellulase enzymes in the production process and the rate of reaction is influenced by several factors, namely $\mathrm{pH}$, temperature, ionic influence, inoculum concentration, incubation time and substrate. Substrate plays a very important role because each type of enzyme can only work on a particular substrate so that not all types of substrates match a type of enzyme. This is because the needs of microorganisms for different substrates. Some need a complete substrate and some can flourish with a very simple substrate. Cellulase enzymes are used to degrade cellulose to sugar (glucose) which is used as an energy source and carbon for cellulolytic mold growth[9]. Cellulase enzyme is an enzyme that can degrade cellulose with its main products namely glucose, cellobiose and cellooligosaccharides. Cellulase has an enzyme system consisting of endo-1,4- $\beta$-glucanase, exo-1,4$\beta$-glucanase, and $\beta$-D-glucosidase [10]. These three enzymes work synergistically to degrade cellulose and release reducing sugars as the final product. Therefore, the right substrate for producing cellulase enzymes is cellulose. Cellulose is an organic compound found in cell walls along with lignin which plays a role in strengthening plant structure. Natural cellulose fibers are found in plant cell walls and other vegetative materials [11]. Cellulose is found in both the crystalline and the non-crystalline structure. The coalescence of several polymer chains leads to the formation of microfibrils, which in turn are united to form fibres. In this way cellulose can obtain a crystalline structure [12]. Cellulose is a compound that is abundant in the world and easily found in nature. Cellulose can be found in agricultural and plantation wastes. The wastes can be in the form of bagasse, rice straw, leaf litter, corn cob, and others.

Madiun Regency is an area that has abundant agricultural waste because many people make a living as rice farmers and gardeners. Agricultural waste is usually not used optimally by the community. With the abundance of agricultural and plantation wastes containing cellulose, it is necessary to conduct research to produce cellulase enzymes from various types of agricultural waste substrates containing cellulose. The application and utilization of cellulase in the industrial sector are hampered by the high price of commercial cellulase on the market today. Production of cellulase enzymes on an industrial scale requires high production costs so that the production of enzymes is expensive. To overcome the problems in the production of enzymes used alternative production substrates, one of which is by utilizing agricultural waste [13].

Agricultural waste substrate that known to have been used in research into the production of cellulase enzymes from Trichoderma viride is bagasse [14]. It obtained the best treatment combination to produce optimal activity of crude cellulase with $3 \%$ substrate concentration treatment and 7 days fermentation time with the average value of cellulase activity (filter paperase), dissolved protein, and cellulase specific activity respectively 0.771 Unit / $\mathrm{mL}, 0.262 \mathrm{mg} / \mathrm{mL}$, and 2.940 Unit / mg. Whereas, a similar study was also conducted by Montesqrit (2007) with rice straw substrate which obtained the results that the maximum cellulase activity of Trichoderma viride was obtained on the $14^{\text {th }}$ day with a substrate concentration of $1.5 \%$ and obtained optimum cellulase activity at $\mathrm{pH} 5$ and temperature of $60^{\circ} \mathrm{C}$. A study using banana peel substrate reported the highest cellulase enzyme activity of CMC-ase was 4.4506 (IU / ml) and FP-ase was $1.4943(\mathrm{IU} / \mathrm{ml})$ on the $12^{\text {th }}$ day [16]. Lanasari (1999) used rhizome of alangalang substrate and found that cellulase activity tended to increase until the $9^{\text {th }}$ incubation time and decreased at the $11^{\text {th }}$ day incubation time. It is estimated that at the $9^{\text {th }}$ day incubation, molds were in the logarithmic phase and produced the highest activity, namely CMC-ase of $0.227 \mathrm{IU} / \mathrm{mL}$, FP-ase of $0.141 \mathrm{IU} / \mathrm{ml}$ and $\beta$-glucosidase of $0.202 \mathrm{IU} / \mathrm{mL}$. Cellulase enzymes that have been produced before being used in the industry must be tested for their enzyme activity. Enzyme activity that is known for its ability can be directly applied to get maximum results [18].

Enzyme activity is defined as the rate of substrate reduction or the speed of product formation at optimum conditions. One unit of enzyme activity is the number of enzymes that can produce $1 \mu \mathrm{mol}$ glucose per minute [19]. Moreover, the specific activity of an enzyme is defined as the number of per milligram protein enzyme units. This study aims to determine the activity of crude cellulase enzymes by 
Trichoderma viride mold produced from various substrates of cellulose waste that are abundant, namely peanuts, coconut fibers, bran, and teak leaves. Trichoderma is filamentous fungi the species of which were previously considered to be culture contaminants. Trichoderma is a very versatile mold: a nuisance for people, a useful fungus for industry and

\section{MATERIALS AND METHODS}

\subsection{Equipments and Materials}

Test tubes, test tube racks, digital scales, hot plate, beaker glass, erlenmeyers, petri dishes, ose needles, bunsen, refrigerators, incubator, autoclave, $\mathrm{pH}$ meter, orbital rotator, centrifuge, centrifuge tubes, volume pipettes, micropipettes, spatulas, microscopes, water bath, spectrophotometer, Whatman No.1 filter paper, $70 \%$ alcohol, aluminum foil, plastic wrapping, sieves, bed linen bottles, lighter. The materials used in this study were peanut shells, coconut fibers, rice bran, teak leaves, Potato Dextrose Agar, distilled water, $4 \%$ $\mathrm{NaOH}$, Urea, $\left(\mathrm{NH}_{4}\right){ }_{2} \mathrm{SO}_{4}, \mathrm{KH}_{2} \mathrm{PO}_{4}, \mathrm{CaCl}_{2} .2 \mathrm{H}_{2} \mathrm{O}$, $\mathrm{MgSO}_{4} .7 \mathrm{H}_{2} \mathrm{O}$, Peptone, Yeast extract, Tween 80, $\mathrm{FeSO}_{4} .7 \mathrm{H}_{2} \mathrm{O}, \quad \mathrm{MnSO}_{4} .7 \mathrm{H}_{2} \mathrm{O}, \quad \mathrm{ZnSO}_{4} .7 \mathrm{H}_{2} \mathrm{O}$, $\mathrm{CoCl}_{2} \cdot 6 \mathrm{H}_{2} \mathrm{O}$ Glucose, 3,5-dinitro salicylic acid, $\mathrm{NaOH}$, Potassium Tartaric, CMC, Buffer citrate phosphate $\mathrm{pH}$ 5, Coomassie Brilliant Blue G-250, 95\% ethanol, phosphoric acid, and Bovin Serum Albumin.

\subsection{Method}

\subsubsection{Substrate preparation.}

Samples of natural substrates (peanut skins, coconut fibers, bran and teak leaves) were cleaned and chopped up to $2 \mathrm{~cm}$ in size then the substrate was mashed using a blender and sieved with a sieve of 60 mesh [21].

\subsubsection{Trichoderma Rejuvenation on PDA media.}

A PDA of 1.95 grams were put into $50 \mathrm{~mL}$ of distilled water and next heated and homogenized. After that, $\pm 5 \mathrm{ml}$ of PDA solution were put into a petri dish and sterilized in an autoclave for 15 minutes at $121^{\circ} \mathrm{C}$. Mold rejuvenation was done by inoculating Trichoderma viride molds into Potato biocontrol and a bane to other fungi. Trichoderma spp. is present in nearly all soils and other diverse habitats. In soil, they frequently are the most prevalent culturable fungi [20]. The results of this study are expected to make a major contribution to the optimization of cellulase enzyme production from microbes

Dextrose Agar (PDA) then incubated at $32^{\circ} \mathrm{C}$ for 6 days [21].

\subsubsection{Delignification of the substrate.}

The substrates that had been blended and sieved were soaked in a $4 \% \mathrm{NaOH}$ solution with a ratio of 1:10 (substrate powder: $4 \% \mathrm{NaOH}$ ) for 24 hours, then the substrates were washed with distilled water to neutral the $\mathrm{pH}$. The neutral $\mathrm{pH}$ condition was stated if the $\mathrm{pH}$ of the water from the substrates was equal to the $\mathrm{pH}$ of distilled water. After that, the substrates sample were dried in an oven at $50^{\circ} \mathrm{C}$ and stored at room temperature for further use as a substrate for Trichoderma viride growth medium.

\subsubsection{Propagation of Trichoderma viride on PDB media.}

PDB as much as 2.4 grams were dissolved in 100 $\mathrm{ml}$ of distilled water and homogenized. The solution was autoclaved for 15 minutes at $121^{\circ} \mathrm{C}$ at a pressure of 15 Psi (2 atm), afterward waited for it to cool. Trichoderma viride in a petri dish were taken with an ose needle and put it in $10 \mathrm{ml}$ of sterile distilled water. The solution was shaken until it was turbid. The turbid solution was put into the Erlenmeyer tubes which already contained a GDP of $90 \mathrm{ml}$. The solution was incubated at room temperature $\left(27{ }^{\circ} \mathrm{C}-30^{\circ} \mathrm{C}\right)$ using an orbital rotator for 6 days [21].

\subsubsection{Acclimatization.}

The purpose of acclimation is to adapt and survive in the environment with a nutrient medium in the enzyme production process. Acclimatization in this study was carried out in two stages, namely acclimatization 1 and acclimatization 2. The following is an acclimatization design table:

Table 1. Percentage of GDP media with acclimatization nutrition media.

\begin{tabular}{llcc}
\hline No & Process & PDB & NutritionMedia (mendels) \\
\cline { 2 - 4 } 1 & Acclimatization I & $50 \%$ & $50 \%$ \\
2 & Acclimatization II & $30 \%$ & $70 \%$ \\
\hline
\end{tabular}




\section{Acclimatization 1}

Nutrient media were weighed and dissolved into distilled water until homogeneous. Waiting until it was cooled to set it in $\mathrm{pH} 5$. Each substrate of 2 grams was put into a glass bottle. Each glass bottle was filled with $18 \mathrm{ml}$ of nutrient solution to autoclave them for 15 minutes at $121^{\circ} \mathrm{C}$. Trichoderma viride that had been augmented in PDB was inserted into bottles which each of them contained substrate and nutrient acclimation media 1 . The corked bottle was incubated at room temperature $\left(27^{\circ} \mathrm{C}-30^{\circ} \mathrm{C}\right)$ using rotary orbital for 6 days [22]. The complete acclimation process 1 is explained in Appendix 2

Acclimatization 2

The nutrient media were weighed and dissolved into distilled water and homogenized. Waiting until it is cold and adjusted to $\mathrm{pH}$ 5. Each substrate of 1.5 grams was put into a glass bottle. Each glass bottle was filled with $135 \mathrm{ml}$ nutrient solution then sterilized in the autoclave for 15 minutes at $121{ }^{\circ} \mathrm{C}$. Trichoderma viride that had been acclimatized 1 was taken as much as $15 \mathrm{ml}$ and put in each bottle containing substrate and nutrient acclimatization media 2 . The corked bottles were incubated at room temperature using rotary orbital for 6 days [22].

\subsubsection{Cellulase enzyme production.}

The production of cellulase enzymes was carried out with nutritional media mendels $100 \%$ without GDP. The nutritional composition of mendels as follows: Urea $0.3 \mathrm{~g} / \mathrm{L},\left(\mathrm{NH}_{4}\right)_{2} \mathrm{SO}_{4} 1.4 \mathrm{~g} / \mathrm{L}$, $\mathrm{KH}_{2} \mathrm{PO}_{4} 2.0 \mathrm{~g} \mathrm{/} \mathrm{L,} \mathrm{CaCl}_{2} .2 \mathrm{H}_{2} \mathrm{O} 0.4 \mathrm{~g} / \mathrm{L}$, $\mathrm{MgSO}_{4} .7 \mathrm{H}_{2} \mathrm{O} 0.3 \mathrm{~g} / \mathrm{L}$, Peptone $0.75 \mathrm{~g} / \mathrm{L}$, Yeast extract $0.25 \mathrm{~g} / \mathrm{L}$, Substrate powder $10 \mathrm{~g} / \mathrm{L}$, Tween $800.2 \mathrm{~g} / \mathrm{L}, \mathrm{MnSO}_{4} .7 \mathrm{H}_{2} \mathrm{O} 1.6 \mathrm{mg} / \mathrm{L}$, $\mathrm{FeSO}_{4} .2 \mathrm{H}_{2} \mathrm{O} 5 \mathrm{mg} / \mathrm{L}, \mathrm{ZnSO}_{4} .7 \mathrm{H}_{2} \mathrm{O} 1.4 \mathrm{mg} / \mathrm{L}$, $\mathrm{CoCl}_{2} \cdot 6 \mathrm{H}_{2} \mathrm{O} 2 \mathrm{mg} / \mathrm{L}$ (Chand, et al. 2005). Nutrition media were weighed and dissolved with distilled water until homogeneous. Next, measure the $\mathrm{pH}$ up to $\mathrm{pH}$ 5. Each substrate with each treatment time was prepared. The substrate weighed as much as 1 gram was put into glass bottles that were labeled according to the research treatment. Each bottle was filled with a nutrient solution for the production media. The bottles were corked with cotton until the next meeting that were autoclaved for 15 minutes at $121^{\circ} \mathrm{C}$. Trichoderma viride that had been acclimatized 2 was taken as much as $10 \mathrm{ml}$ and put in each bottle that already contained substrate and nutritional media for production. The corked bottles were then incubated at $27^{\circ} \mathrm{C}-30^{\circ} \mathrm{C}$ using rotary orbital for 7 days [21].

\subsubsection{Harvesting the cellulase enzymes.}

Enzyme harvesting was carried out on days 1, 3, 5 and 7 during the incubation time. The production solution of each sample was filtered with Whatman filter paper No. 1. Crude cellulase enzymes were obtained by centrifugation of selected samples at a speed of $3000 \mathrm{rpm}$ for 10 minutes [23].

\subsubsection{Determination of protein content \\ (Bradford 1976).}

\subsubsection{Making a standard protein curve}

The standard protein used in this study was Bovine Serum Albumin (BSA) with a concentration of 0.02 to $1 \mathrm{mg} / \mathrm{ml}$. Three $\mathrm{ml}$ of BSA solution was added to $4 \mathrm{ml}$ of Bradford solution. The Bradford reagent was made by mixing Coomassie Brilliant Blue G-250 $100 \mathrm{mg}$, ethanol $95 \% 50 \mathrm{~mL}$, phosphoric acid $85 \% 100$ $\mathrm{mL}$ and distilled water up to 1 liter. The solution was vortexed and incubated for 5 minutes. The absorbance of the solution was then measured with a spectrophotometer at a wavelength of 595 $\mathrm{nm}$ [24].

\subsubsection{Determination of protein content}

The $0.02 \mathrm{ml}$ of cellulase enzyme samples was added in $4 \mathrm{~mL}$ of Bradford solution. The solution was vortexed and incubated for 5 minutes. The absorbance of the solution was measured by a spectrophotometer at a wavelength of $595 \mathrm{~nm}$ [24]. Protein absorbance values are included in the linear equation of the standard BSA curve $\mathrm{y}=$ $a x+b$, where $y=$ protein absorbance of each sample and $\mathrm{x}=$ total protein content.

\subsubsection{Reduction of sugar measurement.}

Cellulase activity was quantitatively carried out using DNS reagents based on the estimated amount of reducing sugar produced from $1 \%$ CMC media. A total of $1 \mathrm{~mL}$ of $1 \%$ CMS media was added to $1 \mathrm{ml}$ of crude cellulase enzyme and put in a tube then incubated at $55^{\circ} \mathrm{C}$ for 15 minutes. A total of $1 \mathrm{ml}$ of DNS reagent was added to stop the reaction and boiled at $100^{\circ} \mathrm{C}$ for 5 minutes. The amount of reducing sugar released was determined by measuring $540 \mathrm{~nm}$ wave length spectrophotometer [25]. After the standard glucose curve was obtained, then the equation line $\mathrm{y}=\mathrm{ax}+\mathrm{b}$ was used to determine the concentration of glucose $(x)$ from the sample to be measured absorbance. 


\subsubsection{Determination of enzyme activity.}

Cellulase enzyme activity was calculated based on data of relative glucose levels as $\mathrm{mg}$ of glucose produced by $1 \mathrm{~mL}$ of crude cellulase filtrate. One unit of enzyme activity was defined as the amount of $1 \mu \mathrm{mol}$ glucose produced from media hydrolysis by $1 \mathrm{~mL}$ of crude extract of cellulase enzyme during the incubation period to see the magnitude of one unit of enzyme activity using the formula [26].

Activity $(\mathrm{U} / \mathrm{ml})=(\mathrm{mg}$ glucose $\mathrm{x} 1000) /(\mathrm{Mr}$ glucose $\mathrm{x}$ t $\mathrm{x}$ V)

Where :

Mr Glucose = Glucose Molecular Weight $(180 \mathrm{~g}$ / mol)

Table 2. Comparison of the value of protein content, sugar content, enzyme activity and specific activity in each treatment.

\begin{tabular}{llllll}
\hline No & $\begin{array}{l}\text { Treatment } \\
\text { combination }\end{array}$ & $\begin{array}{l}\text { Total protein } \\
\text { level }(\mathrm{mg} / \mathrm{ml})\end{array}$ & $\begin{array}{l}\text { Reducing } \\
\text { sugar } \\
(\mathrm{mg} / \mathrm{ml})\end{array}$ & $\begin{array}{l}\text { Enzyme } \\
\text { activity }(\mathrm{U} / \mathrm{ml})\end{array}$ & $\begin{array}{l}\text { Specific } \\
\text { Activity } \\
(\mathrm{U} / \mathrm{mg})\end{array}$ \\
\hline 1 & $\mathrm{~S}_{1} \mathrm{~T}_{1}$ & 0.157 & 0.720 & 0.799 & 5.458 \\
2 & $\mathrm{~S}_{1} \mathrm{~T}_{2}$ & 0.142 & 0.853 & 0.947 & 6.984 \\
3 & $\mathrm{~S}_{1} \mathrm{~T}_{3}$ & 0.174 & 1.062 & 1.179 & 6.826 \\
4 & $\mathrm{~S}_{1} \mathrm{~T}_{4}$ & 0.196 & 1.192 & 1.324 & 6.845 \\
5 & $\mathrm{~S}_{2} \mathrm{~T}_{1}$ & 0.155 & 0.594 & 0.660 & 4.379 \\
6 & $\mathrm{~S}_{2} \mathrm{~T}_{2}$ & 0.095 & 0.828 & 0.920 & 9.726 \\
7 & $\mathrm{~S}_{2} \mathrm{~T}_{3}$ & 0.354 & 1.143 & 1.270 & 3.616 \\
8 & $\mathrm{~S}_{2} \mathrm{~T}_{4}$ & 0.257 & 1.207 & 1.340 & 5.297 \\
9 & $\mathrm{~S}_{3} \mathrm{~T}_{1}$ & 0.026 & 0.827 & 0.918 & 38.663 \\
10 & $\mathrm{~S}_{3} \mathrm{~T}_{2}$ & 0.133 & 0.957 & 1.096 & 14.618 \\
11 & $\mathrm{~S}_{3} \mathrm{~T}_{3}$ & 0.128 & 1.017 & 1.130 & 9.451 \\
12 & $\mathrm{~S}_{3} \mathrm{~T}_{4}$ & 0.188 & 1.085 & 1.205 & 6.773 \\
13 & $\mathrm{~S}_{4} \mathrm{~T}_{1}$ & 0.108 & 0.745 & 0.828 & 7.697 \\
14 & $\mathrm{~S}_{4} \mathrm{~T}_{2}$ & 0.021 & 0.881 & 0.978 & 56.622 \\
15 & $\mathrm{~S}_{4} \mathrm{~T}_{3}$ & 0.153 & 0.992 & 1.102 & 7.226 \\
16 & $\mathrm{~S}_{4} \mathrm{~T}_{4}$ & 0.170 & 1.149 & 1.277 & 7.513 \\
\hline
\end{tabular}

Note: T1 (incubation time 1 day); T2 (incubation time 3 days); T3 (incubation time 5 days); T4 (7 days incubation time); S1 (Peanut Skin Substrate); S2 (coconut fiber skin substrate), S3 (rice bran

substrate); S4 (teak leaf substrate)

The value of protein content was calculated by Bradford method by entering the absorbance value of the sample in a linear equation on the BSA standard curve. Based on the research results obtained by the linear equation $\mathrm{y}=1.2 \mathrm{x}-0.004$ with an $\mathrm{R} 2$ value of 0.996. R2 value approaching 1 indicates that the correlation between the absorbance value and the standard concentration is in a good range. It also indicates that the data obtained from the research results are accurate. The research data showed that the S2T3 treatment (coconut fiber substrate incubation time 5 days) had the highest protein $\begin{array}{ll}\mathrm{t} & =\text { incubation time }(\text { minutes }) \\ \mathrm{V} & =\text { Enzyme Volume }(\mathrm{ml})\end{array}$

\subsubsection{Determination of enzyme-specific activity.}

Determination of cellulase enzyme-specific activity was calculated by the number of enzyme units divided by the amount of protein content. Specific activities are determined by the formula (Amelia, 2012): Specific activity (U / mg) = (enzyme activity) / (protein concentration).

\section{RESULT AND DISCUSSION}

Comparative values of total protein levels, reducing sugars, enzyme activities and enzyme-specific activities can be observed in Table 2 
value of $0.594 \mathrm{mg} / \mathrm{ml}$ contained in the S2T1 treatment (coconut fiber substrate time incubation 1 day) with protein content value of $0.660 \mathrm{U} / \mathrm{ml}$.

Enzyme activity was measured by the DNS method based on the amount of glucose (reducing sugar) produced by cellulose hydrolysis. The highest cellulase enzyme activity of Trichoderma Viride in this study was $1,340 \mathrm{U} / \mathrm{ml}$ which obtained from the treatment of S2T4 (coconut fiber substrate for 7 days incubation time). The lowest activity was obtained from the treatment of S2T1 (coconut fiber substrate for 1 day incubation time) of $0.660 \mathrm{U} / \mathrm{ml}$.

Enzyme specific activity was obtained by dividing the amount of enzyme activity by total protein content per treatment sample. The research data showed that the treatment of S4T2 (teak leaf substrate incubation time 3 days) displayed the highest value of enzyme-specific activity that was equal to $56.622 \mathrm{U} / \mathrm{mg}$ with the enzyme activity of $0.978 \mathrm{U} / \mathrm{mL}$ and total protein content of 0.021 $\mathrm{mg} / \mathrm{ml}$. The lowest cellulase enzyme-specific activity value was obtained from the treatment of S2T3 (coconut fibers with an incubation time of 5 days) of 3,616 $\mathrm{U} / \mathrm{mg}$ with an average enzyme activity of $1,270 \mathrm{U} / \mathrm{ml}$ and total protein content of $0.354 \mathrm{mg} / \mathrm{ml}$.

Based on Figure 1. The results obtained that for each sample cellulase enzyme protein levels in the substrate type treatment and incubation time showed fluctuating values. Explanation of these conditions is related to the need for molds for carbon sources to survive. When carbon demand for mold decreases, mold responds to synthesize cellulase enzymes to break down cellulose in the environment into glucose. In other conditions when carbon requirements for molds are met, molds will respond not to synthesize cellulase enzymes.

Because the cellulase enzyme is a protein, so when the mold is active in synthesizing cellulase the value of its protein content will increase, in other hand when the mold does not actively synthesize cellulase, the value of its protein content will decrease. The fluctuation in the value of protein content tends to decrease at the beginning of fermentation then rises to the 5th and falls on the 6th day [11]. The protein content in crude cellulase enzymes had many non-enzyme proteins, the value of protein content in crude enzymes that are too high or too low is assumed because the protein contained in the crude enzyme (crude enzyme) cellulase is a mixture of enzyme protein and non-enzyme protein [27]

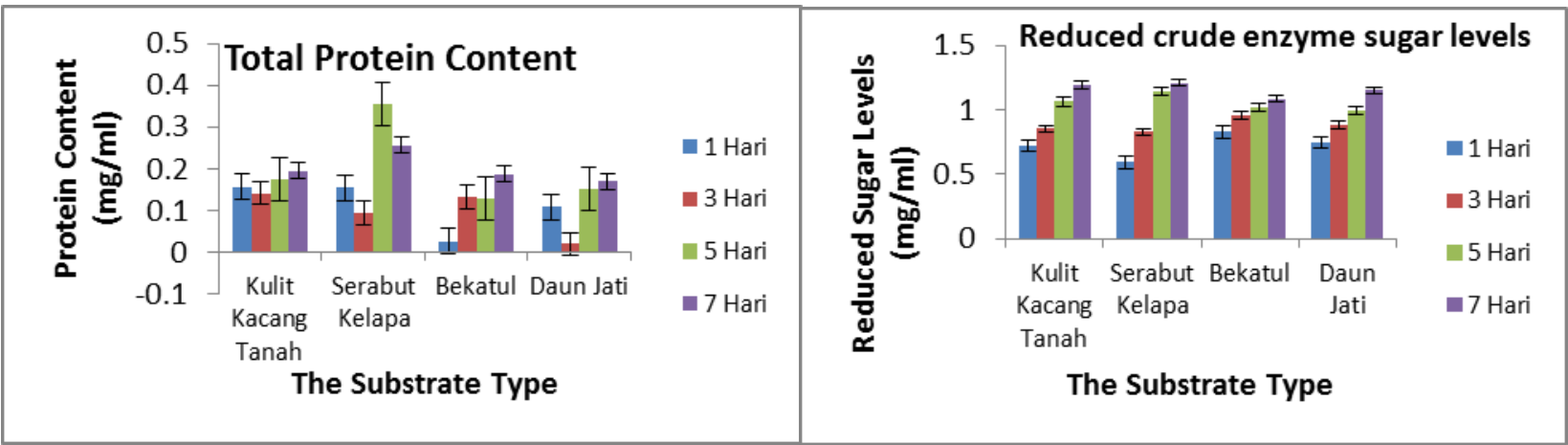

Figure 1. Figure of protein content and reduced sugar levels.

The increase number in protein is in line with mold growth because the mushroom body consists of elements that contains nitrogen [28]. Nitrogen is a constituent component of cell proteins and nucleic acids [27]. Furthermore, the fungal cell walls contain $6.3 \%$ protein while the cell membranes in hyphal fungi contain $25-45 \%$ protein and $25-30 \%$ carbohydrates [28]. So that the protein released by the enzyme also depends on the metabolism of the mold itself in excreting the enzyme which is a protein. The process of cellulose hydrolysis by cellulase will produce reducing sugars in the form of glucose. Reducing sugar levels are measured by the $540 \mathrm{~nm}$ wavelength dinitrosalicylic acid (DNS) method based on the amount of reducing sugar as a result of cellulose hydrolysis. DNS reagents are commonly used in measuring crude sugar reducing enzymes because of their high level of accuracy.

Based on the picture above it can be seen that the value of reducing sugar levels increases with increasing incubation time. The incubation time affects the resulting reducing sugar levels. The condition which is due to the amount of substrate at the beginning of the hydrolysis is still quite large so that with the longer incubation time (hydrolysis), the resulting reducing sugar also increases but also due to sugar as a source of nutrition is still widely available so as to allow reducing sugar levels at a certain time [29]. The incubation time provides an opportunity for Trichoderma viride to multiply cells so that the number of cells produced increase. The increase in 
reducing sugars also shows that the activity of Trichoderma viride in hydrolyzing cellulose into glucose and cellobiose components increases. Cellulose in agricultural waste is the main substrate needed as a carbon source to obtain energy, as well as being degraded to synthesize metabolite products in the form of glucose groups. The results of the analysis of variance showed a significant effect $(\mathrm{p} \leq$ 0.05) due to the treatment of incubation time on reducing sugar levels but did not have a significant effect on the type of substrate. The treatment of coconut fiber substrate for 7 days incubation was the highest substrate concentration. It is assumed that coconut fibers have the highest cellulose content compared to the other three types of substrates (peanut shells, bran, and teak leaves). Also, with the high cellulose content, more cellulose substrates can be hydrolyzed by cellulase enzymes to become monomers so that glucose levels increase.

Cellulase enzyme activity was tested by using the CMC substrate (Carbonmethyl Cellulose) using DNS reagents (3,5-dinitrosalicylic acid) which will be observed based on the amount of glucose formed. Cellulase enzymes are a group of enzymes consisting of several enzymes that work synergistically in breaking down cellulose into glucose by hydrolyzing the $\beta(1,4)$ bond in cellulose. Cellulase activity is measured using CMC (Carbonmethyl Cellulose) because CMC is a cellulose-derived compound [10] and has an amorphous part cellulose structure, so when cellulase enzymes are given the appropriate substrate (cellulose) a cellulose hydrolysis reaction will occur with glucose. The active cellulase enzymes work in the amorphous region of cellulose and produce cellooligosaccharides [30]. Cellulase activity will increase with the length of the cellulose chain to be hydrolyzed. Figure 2. sh owed that the highest cellulase enzyme activity was $1.34 \mathrm{U} / \mathrm{ml}$ occurred in the treatment of Coconut Fiber Substrate with an incubation time of 7 days and the lowest activity was seen on the coconut fiber substrate for d day 1 incubation time with an enzyme activity value of 0.66 $\mathrm{U} / \mathrm{ml}$. When linked to a bar chart, the highest activity value on all types of substrates lies on day $7^{\text {th }}$ while the lowest activity value of all substrates at day 1 incubation time. Enzyme activity will increase with increasing incubation time or fermentation time. The growth phase begins with the lag phase (the adaptation phase) which is the phase in which microorganisms adjust themselves due to changes in the media and environment. This phase occurs shortly after the inoculation takes place where the cell is still relatively fixed [31]. Next is the log phase (growth phase), the growth phase is characterized by a significant increase in the number of cells because the cell division process occurs optimally. The growth phase is the best in determining the optimal time of inoculation of a cell. If related to Figure 2, the 7-day incubation time is the optimal time for cellulase production from Trichoderma viride. The longer the incubation time, the hydrolysis of cellulose into glucose by cellulase enzymes produced by Trichoderma viride is getting higher. Based on these explanations it can be concluded that the higher the glucose produced, the higher the enzyme activity. The cellulase activity would increase at an optimal incubation time, increasing in the number and activity of enzymes causing more and more cellulose-forming bonds ( $\beta-1-1$-glycosides) to be broken down to produce oligosaccharides to eventually be converted into monoglucose, so that levels of cellulose in the fermentation medium decreases [32].

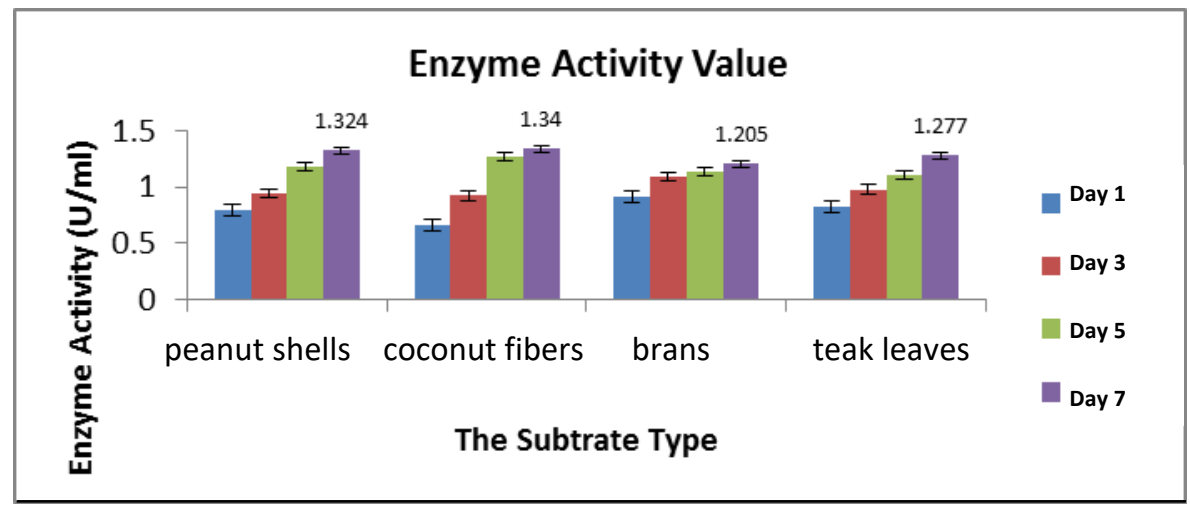

Figure 2. Figure of cellulase enzyme activity. 


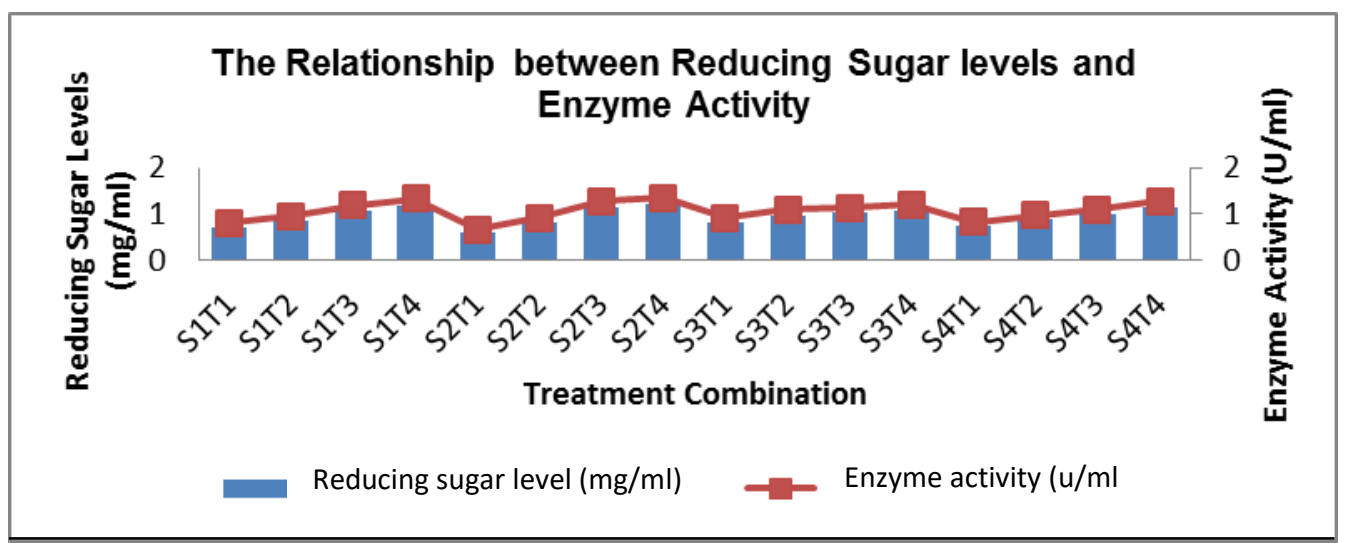

Figure 3. The relationship between reducing sugar levels and enzyme activity

Based on the analysis of variance, the type of substrate does not affect cellulase enzyme activity. However, enzyme activity showed high values on substrates containing high cellulose content and showed lower values on substrates containing less cellulose. On average agricultural waste contains 28 $47 \%$ cellulose and 10-30\% lignin. The presence of lignin that binds to cellulose can interfere with the process of cellulose hydrolysis because the cellulose enzyme only works on the cellulose substrate. If lignin is still bound to cellulose, the active site of the enzyme will not open and it is difficult to hydrolyze cellulose.

The reason of the highest value of activity on coconut fibers is because coconut fibers have the highest cellulose content compared to peanuts, rice bran, and teak leaves. Cellulose in coconut fibers was $47.7 \%$, with other components including 29.9 hemicelluloses, $17.8 \%$ lignin, and $0.8 \%$ ash [33]. Specific activity indicates the degree of purity of the enzyme [34]. Specific activity is always related to enzyme protein levels. The relationship between enzyme protein levels and enzyme activity can be seen in Figure 4.

The value of protein content when viewed from the graph can be seen to follow the value of enzyme activity, namely if the enzyme activity is low, the protein content is also low. In the other hand, if the enzyme activity is high, the protein content is also high. However, the value of the protein content of one substrate is different from the value of the protein content of the other substrate at each incubation time. For example in S1T3 treatment (peanut shells, incubation time 5 days) showed lower protein levels compared to S2T3 treatment (coconut fibers, incubation time 5 days). A high protein released in coconut fibers indicates the presence of other proteins (in addition to cellulase enzymes) which may include other cell wall hydrolyzate enzymes [35]. So that the protein content in coconut fibers is higher than other substrates. The amount of protein released is a function of the complexity of carbon sources. The more complex the carbon source, the greater the amount of protein produced. The specific activity of cellulase enzyme is related to proteins because the value of specific activities can be determined by dividing the activity of enzymes with specific activities [35]. The following graph are the relationship between protein levels on enzyme and specific activities. 


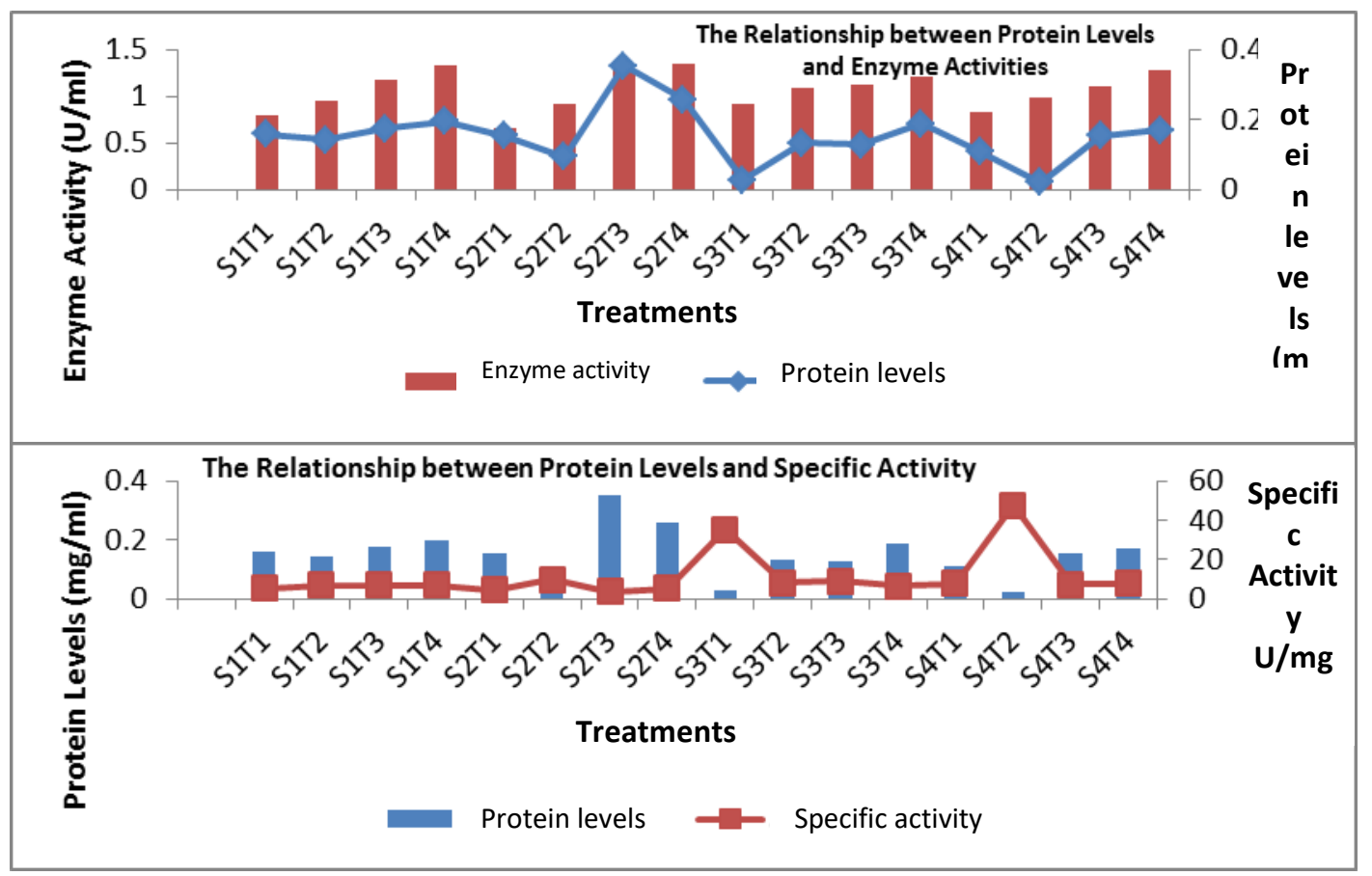

Figure 4. The relationship between protein levels vs enzyme activities and Protein Levels and Specific Activity

The relationship between protein content and specific activities shows that the lower the value of protein content the higher specific activities, conversely if the value of protein content increase, the specific activity will be decrease. The data is supported by another research, that described the value of the protein content of 0.3319 has a specific activity of 1.4462 [36]. The protein content of 0.2883 has a specific activity of 1.8352 and protein content of 0.2778 has a specific activity of 2.77812. In general, enzyme-specific activity testing is carried out for purified enzyme samples. Purification process causes decreased protein levels. Decreased protein levels indicate that other proteins besides cell enzymes are already separated then it causes an increase in enzyme activity because the enzymes can work without interference from other impurities [37].

\section{CONCLUSION}

The substrate types affected to crude cellulase enzyme activity. The highest cellulase enzyme activity of Trichoderma viride in this study was 1,340 $\mathrm{U} / \mathrm{ml}$ was obtained from S2T4 treatment (coconut fiber substrate for 7 days incubation time) and the lowest activity is obtained from the treatment of S2T1 (coconut fiber substrate for 1 day incubation time) of $0.660 \mathrm{U} / \mathrm{ml}$. Based on the value of reducing sugar level shows that the S2T4 treatment (coconut fiber substrate for 7 days incubation time) had a protein content value of $1,207 \mathrm{mg} / \mathrm{ml}$ while the lowest value of $0.594 \mathrm{mg} / \mathrm{ml}$ was found in the S2T1 treatment that was (coconut fiber substrate time incubation 1 day), then the highest protein content was shown in the $\mathrm{S}_{2} \mathrm{~T}_{3}$ treatment (coconut fiber substrate at 5 days incubation) that had the highest protein content with a protein content of $0.354 \mathrm{mg} / \mathrm{ml}$. Whereas the treatment of S4T2 (teak leaf substrate incubation time 3) days showed the lowest percentage of protein with a protein content of 0.021 $\mathrm{mg} / \mathrm{ml}$.

\section{REFERENCES}

[1] A. H. Rahmadani and E. Susanti, "Kajian Potensi Limbah Pertanian Sebagai Sumber Karbon Pada Produksi Avicelase dan CMCase dari Bacillus circulans," J. Kim. Val., vol. 3, no. 2, 2013.

[2] M. Jayant, J. Rashmi, M. Shailendra, and Y. Deepesh, "Production of cellulase by different co-culture of Aspergillus niger and Penicillium chrysogenum from waste paper , cotton waste and baggase," J. Yeast Fungal Res., vol. 2, no. February, pp. 24-27, 2011. 
[3] T. A. A. Moussa and N. A. Tharwat, "Optimization of cellulase and $\beta$-glucosidase induction by sugarbeet pathogen Sclerotium rolfsii," African J. Biotechnol., vol. 6, no. 8, pp. 1048-1054, 2007.

[4] M. Karmakar and R. R. Ray, "Current Trends in Research and Application of Microbial Cellulases," Res. J. Microbiol., vol. 6, no. 1, pp. 41-53, 2011.

[5] I. W. Arnata, "Pengembangan Alternatif Teknologi Bioproses Pembuatan Bioetanol dari Ubi Kayu Menggunakan Tricoderma viride, Aspergillus niger dan Saccharomyces cerevisiae," pp. 1-104, 2009.

[6] E. S. Lymar, B. Li, and V. Renganathan, "Purification and characterization of a cellulose-binding $\quad \beta$-glucosidase from cellulose-degrading cultures of Phanerochaete chrysosporium," Appl. Environ. Microbiol., vol. 61, no. 8, pp. 29762980, 1995.

[7] A. Sulistyarsi, W. Muh. Ardi, and Pujiati, "Uji Aktivitas Crude Enzim Selulase Kapang Penicillium sp pada Ubstrat Ampas Tebu Sebagai Buku Pedoman Model Pembelajaran Berbasis Proyek," pp. 187-192, 2013.

[8] K. Neethu et al., "A novel strain of Trichoderma viride shows complete lignocellulolytic activities," Adv. Biosci. Biotechnol., vol. 03, no. 08, pp. 1160-1166, 2012.

[9] Pujiati; Joko Widiyanto, Kapang Selulolitik, vol. 1, no. 9. Madiun: Program Studi Pendidikan Biologi FPMIPA IKIP PGRI Madiun, 2017, 2017.

[10] P. Purkan, H. Purnama, and S. Sumarsih, "Production of Cellulase Enzyme from Aspergilus niger using Rice Husk and Bagasse as Inducer," J. ILMU DASAR, vol. 16, no. 2, p. 95, 2016.

[11] S. W. Aryani, "Isolasi Dan Karakterisasi Ekstrak Kasar Enzim Selulase dari Kapang Selulolitik Mucor sp.B2,” pp. 1-76, 2012.

[12] P. Harmsen, W. Huijgen, L. Bermudez, and R. Bakker, "Literature review of physical and chemical pretreatment processes for lignocellulosic biomass," 2010.

[13] Pujiati, M. W. Ardhi, and A. Sulistyarsi, "Analisa Kadar Protein Crude Enzim Selulase Dari Kapang Rhizopuz Sp Pada Substrat Ampas Tebu Hasil Isolasi Dari Kebun Cengkeh, Kare, Madiun," Biota, vol. 3, no. 1, p. 26, 2017.

[14] I. B. W. Gunam, W. R. Aryanta, and I. B. N. S. Darma, "Produksi Selulase Kasar Dari Kapang Trichoderma Viride Dengan
Perlakuan Konsentrasi Substrat Ampas Tebu Dan Lama Fermentasi Production Of Crude Cellulase From Trichoderma viride WI ... Production Of Crude Cellulase From Trichoderma Viride With Concentrati," no. April 2015, 2011.

[15] M. Montesqrit, "Isolasi dan Karakterisasi Selulase dari Trichoderma Viride dan Rhizopus Spp dengan Substrat Jerami Padi," J. Peternak. Indones. (Indonesian J. Anim. Sci., vol. 12, no. 2, p. 112, 2007.

[16] H. Murphi, "Pemanfaatan Kulit Buah Pisang untuk Produksi Enzim Selulase oleh Trichoderma viride, Aspergilus niger dan Asperhilus Oryzae," 1994.

[17] Lanasari, "Kajian Waktu Inkubasi Trichoderma viride dengan Substrat Rhizoma Imperata cylindrica dalam Produksi Selulase,” p. 15, 1999.

[18] Pujiati, R. B. Kiswardianta, and W. Solikati, "Pengaruh Konsentrasi dan Lama Inkubasi Terhadap Aktivitas Enzim Selulase dari Kapang Aspergillusniger," J. LPPM, vol. 2, pp. 19-24, 2014.

[19] M. A. Kusumaningati, S. Nurhatika, and A. Muhibuddin, "Potensi Kapang Aspergillus sp. dalam Proses Hidrolisis untuk Produksi Etanol dari Sampah Sayur dan Buah Pasar Wonokromo Surabaya," Makal. Orasi Ilm., pp. 1-13, 2013.

[20] B. K. Mishra, R. K. Mishra, R. C. Mishra, A. K. Tiwari, R. Y. Singh, and A. Dikshit, "Biocontrol efficacy of Trichoderma viride isolates against fungal plant pathogens causing disease in Vigna radiata L .," Arch. Appl. Sci. Res., vol. 3, no. 2, pp. 361-369, 2011.

[21] Pujiati, M. W. Ardhi, and endry. nugroho Prasetyo, Bioteknologi Berbasis Proyek Produksi Purifikasi Enzim Selulase dari Kapang Trichoderma viridae dan Potensinya dalam Bioscouring, 1 st ed. CV. AE GRAFIKA, 2018.

[22] P. Chand, A. Aruna, A. M. Maqsood, and L. V. Rao, "Novel mutation method for increased cellulase production," J. Appl. Microbiol., vol. 98, no. 2, pp. 318-323, 2005.

[23] K. L. Budi, Wijanarka, and E. Kusiyantini, "Aktivitas Enzym Selulase Yang Dihasilkan Oleh Bakteri Serratia marcescens Pada Substrat Jerami," J. Akad. Biol., vol. 7, no. 1, pp. 35-42, 2018.

[24] Y. Oktavia, "Karakterisasi Dan Pemurnian Enzim Selulase Kapang Endofit Dari Lamun (Enhalus sp.)," 2014.

[25] V. Jennifer and G. Thiruneelakandan, 
"Enzymatic Activity of Marine Lactobacillus Species from South," vol. 2, no. 1, pp. 542546, 2015.

[26] A. Amelia, "Pengaruh Variasi Konsentrasi Enzim dan Substrat Terhadap Sakarifikasi Limbah Pengolahan Kertas Menggunakan Enzim Selulase dari Bacillus sp . BPPT CC RK2," Skripsi, 2012.

[27] Nenci, "Isolasi Dan Karakterisasi Selulase Dari Trichoderma Viride Strain T051 Dengan Substrat Jerami," Jakarta, 2012.

[28] S. B. Ariyani, Asmawit, and P. P. Utomo, "Optimasi Waktu Inkubasi Produksi Enzim Selulase Oleh Aspergillus niger Menggunakan Fermentasi Substrat Padat," Biopropal Ind., vol. 5, no. 2, pp. 61-67, 2014.

[29] Kodri, B. D. Argo, and R. Yulianingsih, "Pemanfaatan Enzim Selulase dari Trichoderma Reseei dan Aspergillus Niger sebagai Katalisator Hidrolisis Enzimatik Jerami Padi dengan Pretreatment Microwave," J. Bioproses Komod. Trop., vol. 1, no. 1, pp. 36-43, 2013.

[30] S. Jahangeer et al., "Screening and characterization of fungal cellulases isolated from the native environmental source," Pakistan J. Bot., vol. 37, no. 3, pp. 739-748, 2005.

[31] Y. Maryanty et al., "Produksi Crude Lipase Dari Aspergillus niger Pada Substrat Ongok Menggunakan Metode Fermentasi Fasa Padat," Seminar, pp. 4-5, 2010.

[32] E. Saparianti, T. Dewanti, and S. K. Dhoni, "Hidrolisis Ampas Tebu - Ella, dkk J. Tek. Pert. Vol 5. No. 1 : 1 - 10," vol. 5, no. 1, pp. 1-10, 2012.

[33] G. U. Raju, S. Kumarappa, and V. N. Gaitonde, "Mechanical and physical characterization of agricultural waste reinforced polymer composites," J. Mater. Environ. Sci., vol. 3, no. 5, pp. 907-916, 2012.

[34] P. Keković, "Production and purification of the cellulase enzymatic complex of Trichoderma reesei Rut-C30," 2016.

[35] S. Chinedu, "Growth and cellulase activity of wild-type Aspergillus niger ANL301 in different carbon sources," Can. J. Pure Appl. Sci., vol. 2, no. 2, pp. 357-362, 2008.

[36] N. Hasanah and I. Saskiawan, "Aktivitas selulase isolat jamur dari limbah media tanam jamur merang," Pros. Semin. Nas. Masy. Biodiversitas Indones., vol. 1, no. Imas 2009, pp. 1110-1115, 2015.

[37] Sumardi, A. Suwanto, M. Thenawidjaja, and T. Purwadaria, "Isolation and
Characterization of Mannanolytic Thermophilic Bacteria From Palm Oil Shell and Their Mannanase Enzyme Production Properties," Biotropia (Bogor)., vol. 0, no. 25, 2005. 